\title{
JUURNAL.RU
}

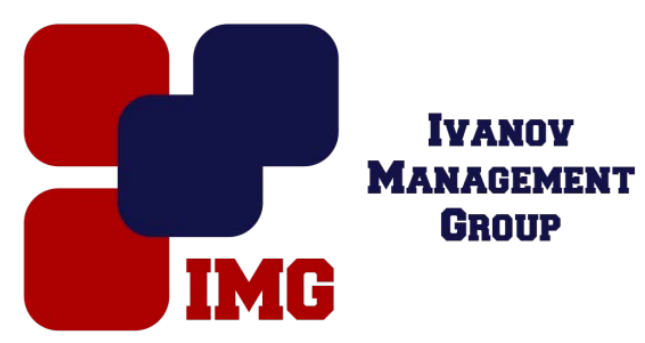

Татьянин Д.В. Удмуртский государственный университет Ижевск, Россия

doi: 10.18411/lj-30-04-2017-3-16

idsp 000001:1j-30-04-2017-3-16

\section{Основания проведения служебной проверки по фактам принятия необоснованных решений при проверке сообщений о преступлениях}

Производство в стадии возбуждения уголовного дела находится в центре внимания в силу того, что от своевременности и качества установления факта совершения преступления зависит его дальнейшее расследование. В то же время проводимая проверка поводов и оснований к возбуждению уголовного дела вызывает большое количество нареканий. Во-первых, проверка проводится в неоправданно длительные сроки, что лишает право на защиту участников предполагаемого уголовно-правового конфликта. Во-вторых, большое количество постановлений об отказе в возбуждении уголовного дела обжалуются не только в ведомственном, но и в судебном порядке, при этом обжалуемые решения отменяются, либо признаются судом незаконными и необоснованными. Логично возникает вопрос о последствиях неоднократного принятия аналогичных отмененных или признанных незаконными решений по одному материалу.

Согласно пункта 13 Инструкции [1], основанием для проведения служебной проверки является необходимость выявления причин, характера и обстоятельств совершенного сотрудником дисциплинарного проступка, подтверждения наличия или отсутствия обстоятельств, предусмотренных статьей 29 Федерального закона от 7 февраля 2011 г. № 3-Ф3 «О полиции», а также заявление сотрудника.

Дисциплинарный проступок представляет собой противоправное виновное нарушение трудовой или служебной дисциплины сотрудником, за которое предусмотрена дисциплинарная ответственность. Дисциплинарный 
проступок характеризуется следующими признаками: неисполнение или ненадлежащее исполнение трудовых обязанностей конкретным сотрудником; нарушенные обязанности сотрудник должен выполнять в рамках трудового договора или иных локальных актов организации; нарушение совершено виновно. Для признания совершения дисциплинарного проступка должны наличествовать все указанные признаки.

Наличие судебного решения или постановления прокурора о признании незаконными действий (решений) сотрудника органа внутренних дел по результатам проведенной проверки сообщения о готовящемся или совершенном преступлении может рассматриваться как основание для проведения служебной проверки в случае, если указанные решения были направлены руководителю органа внутренних дел для проведения служебной проверки. В рамках проведения служебной проверки по указанным фактам следует учитывать, что сам факт принятия неоднократно решения по материалам проверки, отмененного в последующем в порядке прокурорского надзора или в порядке рассмотрения жалобы в порядке ст. 125 УПК РФ, не является в безусловном порядке дисциплинарным проступком. Для того, чтобы установить наличие последнего, следует доказать наличие всех его признаков, поскольку отсутствие хотя бы одного из них не позволяет говорить о совершении дисциплинарного проступка.

При установлении признаков дисциплинарного проступка в действиях сотрудника ОВД при принятии решения по материалам проверки необходимо доказать виновность. Действия сотрудников, принимающих решения по материалам проверки, осуществляемые ими в рамках реализации должностных полномочий, всегда связаны с определенной долей риска, который может выразиться в правоприменительной ошибке. Сам факт правоприменительной ошибки, которая выражается в форме признания судом или прокурором незаконным решения либо деяния сотрудника, не свидетельствует о наличии в действиях сотрудника вины [2, с. 170-171].

Для проведения служебной проверки по факту незаконного и необоснованного принятия решения об отказе в возбуждении уголовного дела на имя должностного лица, правомочного устранить нарушения, должно поступить заявление заинтересованного лица, либо представление прокурора или его заместителя об устранении нарушений закона. Наличие одного из указанных обращений должно выступать безусловным основанием для проведения служебной проверки. В процессе ее проведения должны быть 
исследованы причины неоднократного принятия решения об отказе в возбуждении уголовного дела и его отмене. При этом следует учитывать, что указанные решения принимаются на основании собранных по делу доказательств с учетом усмотрения правоприменителя, принимающего решение в рассматриваемой стадии. Решение об отказе в возбуждении уголовного дела повторно должно приниматься только в случае установления новых обстоятельств, подтверждающих обоснованность ранее принятого, но отмененного решения. Принятие повторного решения при отсутствии новых доказательств недопустимо. В случае установления фактов принятия повторных решений об отказе в возбуждении уголовного дела по одним и тем же основаниям, в отношении лица, принимающего их следует решать вопрос о дисциплинарной ответственности, поскольку в указанном случае можно рассматривать злоупотребления правом сотрудником органа дознания или следователя, принимающего аналогичные решения на основании одних и тех же доказательств. Принятие повторно на одних и тех же основаниях признанных незаконными решений совершается осознанно и виновно, что позволяет говорить о совершении дисциплинарных проступков и необходимости проведений служебной проверки.

1. Об утверждении порядка проведения служебной проверки в органах, организациях и подразделениях Министерства внутренних дел Российской Федерации: Приказ МВД России от 26 марта 2013 г. № 161 (ред. от 22.09.2015) // Российская газета. 2013. № 127 (14 июня).

2. Малыхина Т.А. Дисциплинарное производство в органах внутренних дел Российской Федерации: монография. Ижевск, 2017. 172 с. 